the Apothecaries' Company," from the lat ter of whom the governors and directors are chosen, who go throngh the form of an elec. thon in the month of August of each yearthe sime men (with one or two except.ous perhaps) being invariably re-elected, whence it happens as a matter of course that no change or improvement is to be expect. ed-such being, to all intents and purposes, a perennial, and not an annual directory. In order to become eligible for the office of a director, you must be a shareholder (i. e. a proprietor), for which your pocket must be accountable in the sum of $330 l$. or 30 l. Now it so happens that the poverty of the profession is so great, that few, very few indeed, can command that sum, the result of which is, that many highly-talented and eminently-gifted men are debarred trom taking a part in the management of their profession-a man's capability for taking office in that august body, being rated according to the dimensions of his purse, and not of his understanding. Were I but to mention the various charges and complaints made against this " ruling power," your patience would be exhausted, and my time unprofitably spent in entering into disgraceful details. Suffice it to say, that at last a spirit of reform has evinced itself amongst us : for our leader, we have gotten a man of the most unflinching, upright, and uncompromising priuciples. A man who is the most eminent in the profession of this country, and whose name has shed lustre on the pages of science at loome and abroad. Professor Donovan is the individual $I$ al. lude to, who, disgusted with the illiberal line of policy pursued by the Mary Street junto towards his professional brethren, and finding their understanding so stultified in that corrupt corporation (except so far as regarded pounds, shillings, and pence), de. clined acting as their governor, when ho found all his efforts towards remedying the abuses so loudly complained of, were treated with neglect and scorn; his liberal and highly-cultıvated mind could not tolerate or countenance their selfish and narrowminded form of government. Under his auspices, therefore, 350 out of 1000 apothecaries in Ireland are now appealing, and with confidence, both to the mperial parliament and an enlight $\leqslant$ ned administration, for a redress of great grievances and for freedom from the degrading bondage in which they have been fettered by the inefficiency andignorance of a few dozen of overbearing and purse-proud monopolizers. On a future occasion I shall again recur to this subject, and in the mean time subscribe myself, yours, \&c.,

A Zealous Irish Medical Reformer.

Dublin, Feb. 1, 1831.
FONOURABLE CONDUCT OF DR. ADDISON AT GUY'S HOSPITAL.

To the Editor of $\mathrm{T}_{\mathrm{H}} \mathrm{L} \mathrm{L}_{\mathrm{A}} \mathrm{NeT}$.

Sir,-Believing that nothing which in the slighrest degree affects the interest of the medical student will be considered unworthy of notice by you, I shall not apologise for addressing you upon the following subject. You are aware tbat the lecturer on materia medica at Guy's Hospital professes (in the hospital prospectus annually published) to give lectures twice a week, viz., Tuesday and Friday evenings. Finding, however, soon after the commencement of the course, that he could not get through the series of lectures in the prescribed term of four months, and at the same time do that ample justuce to his subject which he wished (and which every one in the habit of hearing Dr. Addison will allow that he does), he determined to give a third lecture every Wednesday morning; and this hecontinued to do till, in consequence of hasing received some intimation from a portion of his class, who were attached to another school of anatomy and medicine in the neighbourhond, that the hour of lecture (half- past nine A.M.) on Wednesdays, prevented their attending another course of lectures which was de. livered at the said schonl, but that if it were altered to nine o'clock, it would not interfere with such course of lectures. I say, in consequence of an intimation of this kind, Ur. Addison proposed to the class, on 'Tuesday evening last, that the Wednesday's lecture should commence at nine instead of half-past, and this proposition he put to the vote, promising, that if the majority were against the measure, he would return the money of those wilh whose arrangiments (made under an idea of there being but two lectures delivered in a week) the Wednesday lecture of half-past nine interfered. 'The majority, Sir, (influenced, perhaps, by that spirit of party into which it is so natural for young men to enter without nuch consileration) decided against the alteration; and the consfquence which must result from this decision is, that the lecturer (acting, as he doubtless will, up to his promise) will have to return upwards of a hundred guineas (the number of the minority exceeding twenty-five), solely and entirely through his honourable and conscientious conduct in resolving to treat his subject in the fullest and most sitisfactory manner, since by cutting off the extra lecture he might of course have retained the whole sum. It is not often, Mr. Editor, that we see lecturers executing, or desirous of executing, more than they professed or engaced to do; nor is ic an example very likely to be followed, when, as in this instance, a lecturer will lose a considerable sum merely because (to 
use a vulgar metaphor) he is desirous of presenting the students with a better article than they bargained for. I am aware of the unpopularity of materia medica lectures in general; no one, I think, however, who attends these will fail to allow them to be in the highest degree practical, comprehensive, and interesting. In addressing you upon the subject, Sir, in this very imper. fect and hasty manner, I am actuated by no other motive than an earnest desire to see endeavours of so disinterested a nature to add to the acquirements and benefit of the pupil, encouraged rather than repressed, and by a sense of regret at witnessing the silent appeal made to the liberality and good feeling of the class rejected. I have not the pleasure of Dr. Addison's acquaintance, neither am I attached to any other school than Guy's. Will you, Mr. Editor, with your accustomed kindness, give some slight hint upon this subject in au early number of your truly valuable periodical, and by so doing prove yourself to remain (now as well as before being so great a politician) the pupil's friend. Yours respectfully,

Guyensis A.

\section{SCIENTITIC BONE-BETTERS.}

\section{To the Editor of THE Larcet.}

Stn,-Seeing in your valuable publica. tion an account of Drs. Trolly, Mason, and Co., I give you a super-excellent case of one of these worthies. A tradesman, an inhabitant of a market town ten miles from Boston, took a son about ten years old to Dr. Trolly; when he went into the roum, the Doctor was torturing a lad, a pauper (sent by the parish authorities from the same place), by attempting to straighten a contracted linee with diseased bone. When it came to the little patient's turn the father stripped him, and took him forward to the Doctor, who immediately exclaimed, without making any inquiry as to the cause or situation of the injury, or taking an examination, that the left shoulder was out; and after pulling him about for five or ten minutes, told bim, " he had set it," placed the arm in a sling, received his fee and dismissed him. When he returned, his mother perceiving that the sling was not put upon the arm that was injured (which, by-the-by, had escaped the notice of the father), sent for me, when $I$ found the right clavicle was fractured, which being treated in the usual manner, soon enabled him to use his arm as before, proving that " the regular doctors know something of bone-setting." I am, Sir, Yours,

A Surgeon-Apothecary.

Donington, near Spalding, Lincolnalsire.

\section{CASE IN WHICH}

\section{A FOETUS WAS PASSED BI} THE ANUS.

\section{By John Davies, Esq., Surgeon, Coleslill.}

I was required for the first time, Mar the 10 th, 1826, to visit Mrs. C., æetal. 30 , thin delicate-looking woman, on account of an accession of febrile symptoms, when I received from the patient and her attend. ants the following history of her case.

She had been married several years, and enjoyed unin terrupted health until the month of February, 1825, when she had reason, from the signs usually indicating that state, to believe she was pregnant for the first time. Soon after the commencement of the second month, according to ber calculation, she received a sudden shock from a fall, which was speedily followed by uterine dis. charge, that continued in variable quantity for three weeks, at the end of which period pains came on resembling those of labour, accompanied with frequent desire to make water; and a tumour, supposed to be the child, could be felt on the left side of the abdomen, so that it was considered the pa. tient was about to miscarry; the pans however went off, though she contisued very unwell until the middle of the seventh month, when they returned with redoubled violence, attended with most distressing sickness. The tumour was now, by ler own account, most perceptible on the oppo* site side of the abdomen to that it first occu. pied, to which place it moved during the pains, and here it ever afterwards continued.

She was, at this stage of her complaint, attended by $\mathrm{Mr}$. - a surgeon of ac. knowledged talent and ability, who states, in answer to my inquiries on this subject, that he was unable, on examination by the vagina, to detect the os uteri; that her pains were violent, resembling those of la. bour, and that they continued for some space without producing any other effect on the system than that of reducing her strength very much; indeed, the patient herself asserts, that at this period of leer sufferings, she was unable to turn berself in bed for at least a month without assistance, and that the pains never entirely left her until November, when, for the first time since $J$ anuary, she experienced a return of the menstrual discharge, which continued to appear at intervals of five weeks or a month, till she became an inhabitant of Coleshill in February, 1826, and from this period until I first visited her, which, as I before mentioned, was in the May of the same year. Hearing this history of her case, and from her leucophlegmatic appes. ance, I was induced to suspect she ras la. bouring under some disease of the uterus, 